\title{
ESTABLISHING AN EQUAL PLAYING FIELD FOR CRIMINAL DEFENDANTS IN THE AFTERMATH OF UNITED STATES $V$. SINGLETON
}

\author{
KORIN K. EWING
}

\section{INTRODUCTION}

On July 1, 1998, the United States Court of Appeals for the Tenth Circuit announced its opinion in United States v. Singleton ("Singleton I"), declaring that federal prosecutors violate the federal gratuity statute when they offer plea bargains to criminal defendants in exchange for testimony against other criminal defendants. ${ }^{2}$ Only nine days after this stunning opinion was issued, the Tenth Circuit vacated Singleton I for a rehearing of the case en banc. ${ }^{3}$ In January of 1999, the Tenth Circuit issued its opinion in United States v. Singleton ("Singleton II"), ${ }^{4}$ overruling Singleton I and holding that federal prosecutors do not violate the federal gratuity statute by exchanging plea bargains for testimony because the statute does not apply to the government or its agents. ${ }^{5}$ During the six months between Singleton I and Singleton II, over four dozen courts published opinions on whether exchanging reduced sentences for testimony violates the federal gratuity statute. ${ }^{6}$ The high level of judicial activity during this brief period demonstrates the sizable impact that the Singleton I holding had on the legal system.

1. 144 F.3d 1343 (10th Cir. 1998) [hereinafter Singleton I].

2. See id. at 1357-58.

3. See id. at 1361.

4. 165 F.3d 1297 (10th Cir.) (en banc), cert. denied, 119 S. Ct. 2371 (1999) [hereinafter Singleton II].

5. See id. at 1298 .

6. See, e.g., United States v. Ware, 161 F.3d 414, 418 (6th Cir. 1998) (collecting cases), cert. denied, 119 S. Ct. 1348 (1999); United States v. Abraham, 29 F. Supp. 2d 206, 209-10 (D.N.J. 1998) (collecting cases). 
The federal gratuity statute is part of 18 U.S.C. $\S 201(c)(2)$, which proscribes bribery and gratuity. Bribery and gratuity offenses both involve illegally exchanging something of value for some action or behavior, such as payment made to a politician in exchange for her vote in favor of a bill. Bribery and gratuity are distinguished from one another by the intent requirement of each offense. Bribery requires that the person making the offer intend to induce corrupt action or behavior from the recipient. ${ }^{7}$ Gratuity involves essentially the same conduct as bribery but is a lesser offense because it does not require that the offeror actually intend to cause corruption. ${ }^{8}$ A prosecutor who offers to reduce a convicted felon's prison sentence in exchange for the felon's knowingly false testimony against another criminal defendant is guilty of bribery under subsection 201(c)(1). The question at issue in the Singleton cases was whether a prosecutor commits the offense of gratuity, proscribed by subsection 201(c)(2), by offering a criminal defendant a reduced sentence in exchange for what the prosecutor believes will be truthful testimony against another defendant.

Although the holding in Singleton I was quickly vacated and replaced by the contrary holding of Singleton II, the Singleton I panel opened the door to a line of reasoning and argument-that federal plea bargains are illegal under the gratuity statute-that will likely resurface frequently until the Supreme Court issues an opinion on the appropriate interpretation and application of subsection 201(c)(2). ${ }^{9}$ The decision in Singleton II, which accords with most case law interpreting subsection 201(c)(2) subsequent to Singleton I, may be the expedient and simple resolution to arguments based on the Singleton $I$ holding, but in this case that answer is neither a reasonable interpretation of the statute nor an adequate means of maintaining a fair and effective criminal justice system.

A fair and effective criminal justice system is one that affords prosecutors sufficient powers to obtain criminal convictions while preserving for defendants the rights necessary for a just trial. Reading a government exception into subsection 201(c)(2), as did the Singleton II court, is not an adequate resolution of the issue because that in-

7. See 18 U.S.C. $\$ 201(b)$ (1994).

8. See id. $\S 201(\mathrm{c})(2)$.

9. As the Supreme Court declined to grant certiorari in Singleton II, this interpretation is unlikely to occur in the foreseeable future. See United States v. Singleton, 119 S. Ct. 2371 (1999) (denying certiorari). 
terpretation sacrifices the protections the gratuity statute affords to criminal defendants and expands the powers of federal prosecutors. Under the Singleton II interpretation, federal prosecutors are not limited by subsection 201(c)(2), and thus they are not limited in what they may offer potential witnesses to induce them to testify. This gives federal prosecutors unfair bargaining power over defendants, who are constrained by subsection 201(c)(2). Reading the gratuity statute as wholly prohibiting federal prosecutors from exchanging plea agreements with criminal defendants for testimony, as the Singleton I court did, is also unsatisfactory, given how deeply ingrained plea bargaining is in our criminal justice system and how severely its banishment would hamper the ability of prosecutors to obtain criminal convictions against co-defendants. Prohibition of all plea bargains would protect the interests of criminal defendants by reducing the chance that co-defendants would be induced by plea agreements to testify falsely against them, but this reading of subsection 201(c)(2) would make it very difficult for the criminal justice system to function.

There is, however, an alternative to forcing subsection 201(c)(2) into either the Singleton I or the Singleton II interpretation-a solution that balances the interest of criminal defendants in receiving a fair trial and the interest of the government in maintaining an effective criminal justice system. The solution to this semantic nightmare is to repeal subsection 201(c)(2) altogether, allowing prosecutors and defendants alike to exchange consideration for testimony and requiring only that both sides fully disclose any such arrangement to the jury. ${ }^{10}$ Subsection $201(\mathrm{~b})$, the bribery statute, would continue to prohibit offers and deals made with intent to influence the content of a witness's testimony, but attorneys on both sides of the aisle would be free to offer consideration to encourage reluctant witnesses to testify. Since federal prosecutors are currently required to disclose the details of the plea agreements that they offer in exchange for testimony, this new rule would afford defense attorneys the same opportunity to encourage reluctant witnesses to testify, provided that they, too, met the disclosure requirements. Of course, a defense attorney, unlike a prosecutor, could not offer leniency or a reduced sentence in ex-

10. A companion to the gratuity statute criminalizes accepting anything of value offered for, or because of, testimony under oath or affirmation. See 18 U.S. $§ 201(c)(3)$. The discussion of $\S 201$ (c)(2) herein applies equally to $\S 201$ (c)(3). However, since only $\S 201$ (c)(2) has come under fire and debate, that is the focus of this Note. Repealing $\$ 201(\mathrm{c})(2)$ would not accomplish the objectives sought if $\S 201$ (c)(3) were not also repealed. 
change for testimony as could a prosecutor, but the defense attorney could offer other incentives to witnesses who otherwise might be unwilling to testify. Full disclosure of consideration paid in exchange for a witness's testimony would leave to the jury the determination of whether the agreement affected the content of a particular witness's testimony. Repealing subsection 201(c)(2) and replacing it with this disclosure rule is the only fair answer to the dichotomous and unsatisfactory interpretations of the federal gratuity statute offered in Singleton I and Singleton II.

This Note considers both Singleton decisions and the various interpretations of subsection 201(c)(2) offered in those cases and their progeny. It proposes that repealing subsection 201(c)(2) is the most reasonable way both to resolve the conflicting interpretations of the statute and to maximize the fairness and effectiveness of the criminal justice system. Part I of this Note reviews the origins and development of the explosive debate over the proper interpretation of subsection 201(c)(2) in the federal judiciary. Part II analyzes the plain meaning and legislative history of subsection 201(c) both independently and as discussed in federal case law. Part III evaluates the competing judicial interpretations of subsection 201(c)(2), comparing the strongest arguments for and against excluding the government and its agents from the reach of the gratuity statute. Part IV considers the failure of these competing judicial interpretations to address or redress the fundamental imbalance created by allowing prosecutors, but not defendants, to make deals with potential witnesses to encourage testimony. Part IV then proposes the repeal of subsection 201(c)(2) in favor of a rule that allows federal prosecutors and defendants alike to exchange consideration for testimony provided that such arrangements are disclosed to the jury.

\section{UNited States V. SingLETON: THE BeginNing OF THE BATTLE}

An investigation of a conspiracy to launder drug money and to distribute cocaine culminated in the arrest of Sonya Evette Singleton, Napoleon Douglas, and several other individuals. ${ }^{11}$ Douglas entered into a plea agreement with the government, promising to testify against Singleton and other defendants in return for promises by the government (1) not to prosecute Douglas for any other criminal acts related to the narcotics investigation, (2) to inform the court of the

11. See Singleton I, 144 F.3d 1343, 1343-44 (10th Cir. 1998). 
nature and extent of Douglas's cooperation, and (3) to advise the state parole board of the nature and extent of Douglas's cooperation. ${ }^{12}$

Singleton challenged the admissibility of Douglas's testimony, alleging that the plea bargain federal prosecutors had offered Douglas violated the federal gratuity statute. ${ }^{13}$ The trial court overruled Singleton's objection, allowing Douglas to testify, and Singleton was convicted. ${ }^{14}$ Singleton appealed, alleging that admission of Douglas's testimony was reversible error. ${ }^{15}$

The U.S. Court of Appeals for the Tenth Circuit reviewed Singleton's appeal and, in a detailed opinion written by Judge Kelly, considered four possible reasons for excluding federal prosecutors from the federal gratuity statute. The court rejected each reason, concluding that none justified excluding the government from the broad language of subsection 201(c)(2). Thus, the Singleton I court held that federal prosecutors violate the federal gratuity statute when they plea bargain with witnesses to induce them to testify. ${ }^{16}$ The unanimous Tenth Circuit panel reversed Singleton's conviction and remanded the case for a new trial, in which Douglas's illegally obtained testimony would be excluded. ${ }^{17}$

The Singleton I decision had quick and widespread aftershocks. ${ }^{18}$ Although a few courts supported the decision, ${ }^{19}$ most did

\footnotetext{
12. See id. at 1344 .

13. See id. at 1343 .

14. See id. at 1343-44.

15. See id. at 1343 .

16. See id. at $1344-58$.

17. See id. at 1361 .

18. See, e.g., United States v. Eisenhardt, 10 F. Supp. 2d 521, 521-22 (D. Md. 1998) (calling the Singleton I opinion "amazingly unsound, not to mention nonsensical" and offering that " $[\mathrm{t}] \mathrm{he}$ chances of either or both the Fourth Circuit and the Supreme Court reaching the same conclusion as the Singleton panel are, in this Court's judgment, about the same as discovering that the entire roster of the Baltimore Orioles consists of cleverly disguised leprechauns"); United States v. Duncan, No. Crim.A. 97-217, 1998 WL 419503, at *1 (E.D. La. July 15, 1998) (denying a motion for a new trial based on the Singleton I opinion).

19. See United States v. Revis, 22 F. Supp. 2d 1242, 1249 (N.D. Okla. 1998) (agreeing with Singleton I's statutory interpretation of $\S 201$ (c), although ultimately holding that specific provisions of $\S 5 \mathrm{~K} 1.1$, the section of the federal sentencing guidelines authorizing a downward departure in sentencing where the defendant has provided substantial assistance to the government, allowed the instant plea bargain in exchange for testimony); United States v. Fraguela, No. Crim.A. 96-0339, 1998 WL 560352, at*1 (E.D. La. Aug. 27, 1998) (granting defendant's motion for a new trial on the ground that "the testimony of several pivotal witnesses against him was procured in violation of 18 U.S.C. $\S 201(\mathrm{c})(2)$ "), vacated on other grounds, No. Crim.A. 96-339, 1998 WL 910219, at *2 (E.D. La. Oct. 7, 1998); United States v. Lowery, 15 F. Supp. 2d 1348,
} 
not. ${ }^{20}$ In fact, only two district courts have followed the decision in Singleton I, and one of those has been reversed on appeal. ${ }^{21}$ On January 8, 1999, the Tenth Circuit itself issued an en banc opinion in Singleton II, reversing the short-lived holding in Singleton $I^{22}$ Yet, the reasoning in Singleton $I$, which gave credibility to reading subsection 201(c)(2) as applying to agents of the federal government, has since been used frequently by defendants in both federal and state courts. ${ }^{23}$ None of the courts that have considered arguments similar to the reasoning in Singleton $I$ have satisfactorily dispelled the Singleton I analysis. $^{24}$

Most of the federal courts that have evaluated whether subsection 201(c)(2) applies to plea bargaining in the aftermath of Singleton $I$ have provided little or no legal analysis of the issue. Instead, these courts have either cited the reasoning offered in earlier court opinions that had rejected the analysis of Singleton I or declined to follow Sin-

1350 (S.D. Fla. 1998) (granting a motion to suppress the anticipated testimony of three codefendants because "the plea agreements ... violate the clear and unambiguous meaning of section 201(c)(2)"), rev'd, 166 F.3d 1119 (11th Cir.), cert. denied, 120 S. Ct. 212 (1999).

20. See, e.g., United States v. Abraham, 29 F. Supp. 2d 206, 209-10 (D.N.J. 1998) (collecting cases). Many courts have refused to consider motions premised on the Singleton I holding on the ground that the decision was vacated and cannot serve as a legal foundation. See, e.g., United States v. Carroll, Nos. 97-4022, 97-4259, 1998 WL 801880, at*3 n.4 (4th Cir. Nov. 19, 1998); United States v. Jones, 160 F.3d 473, 482 (8th Cir. 1998); United States v. Romero, No. 97CR.650 (LMM), 1998 WL 788799, at *4 n.3 (S.D.N.Y. Nov. 10, 1998); United States v. Buckley, No. 98-40026-02-RDR, 1998 WL 774634, at*1 (D. Kan. Oct. 7, 1998); United States v. Rucker, No. 98-40071-01-RDR, 1998 WL 682252, at *1 (D. Kan. Sept. 18, 1998); United States v. Polidoro, No. CIV.A. 97-383-02, 1998 WL 634921, at*5 (E.D. Pa. Sept. 16, 1998); United States v. Durham, No. 98-10051-02, 1998 WL 684241, at*1 (D. Kan. Sept. 11, 1998); United States v. Garcia, No. CRIM.3:97CR48 (AHN), 1998 WL 744102, at *2 n.1 (D. Conn. Sept. 9, 1998); United States v. Allen, Nos. CRIM.A. 93-36-1, 97-CV-4698, 1998 WL 575264, at *4 n.8 (E.D. Pa. Sept. 2, 1998); United States v. McGuire, 21 F. Supp. 2d 1264, 1266 (D. Kan. 1998); United States v. Pungitore, 15 F. Supp. 2d 705, 711 n.2 (E.D. Pa. 1998); United States v. Duncan, No. Crim.A 97-217, 1998 WL 419503, at*1 (E.D. La. July 15, 1998).

21. See Lowery, 15 F. Supp. 2d at 1348, rev'd, 166 F.3d 1119 (11th Cir.), cert. denied, $120 \mathrm{~S}$. Ct. 212 (1999); Fraguela, No. CRIM.A. 96-0339, 1998 WL 560352, at *1, vacated on other grounds, 1998 WL 910219 (E.D. La. Oct. 7, 1998).

22. See 165 F.3d 1297 (10th Cir.) (en banc), cert. denied, 119 S. Ct. 2371 (1999).

23. See, e.g., United States v. Miles, No. 98-3202, 2000 WL 121281, at *4 (10th Cir. Feb. 1, 2000); United States v. Owusu, 199 F.3d 329, 341 (6th Cir. 2000); United States v. Bidloff, No. 97-CR-233A, 2000 WL 122337, at *5-*13 (W.D.N.Y. Jan. 24, 2000); State v. Coleman, Nos. 99AP-139, 99-AP-140, 2000 WL 38359, at *2-*3 (Ohio Ct. App. Jan. 20, 2000); State v. Warfield, No. 18111-1-III, 2000 WL 85327, at *7-*8 (Wash. Ct. App. Jan. 27, 2000).

24. For a discussion of the necessity of a legislative, rather than judicial, remedy to the ambiguity in $\S 201(\mathrm{c})(2)$, see infra Part IV. 
gleton I because it did not comport with longstanding common law and practice. ${ }^{25}$

To understand the conflict between the Singleton I and Singleton II cases and their progeny, one must consider principles of statutory construction, public policy, and judicial precedent. We begin with an examination of the statute's text and legislative history. ${ }^{26}$

25. See United States v. Masciandaro, No. CR.305 (SHS), 1998 WL 814637, at *1 (S.D.N.Y. Nov. 19, 1998) (denying a post-trial motion for judgment of acquittal because (1) "[t]he long standing practice of promising leniency to cooperating accomplices who agree to testify has been consistently recognized and judicially approved" (citations omitted); (2) "[n]umerous statutes enacted by Congress implicitly reveal its approval of the practice" (citations omitted); and (3) "nearly every district court that has considered the present issue has rejected the Singleton [I] court's analysis" (citing United States v. Meija, No. 8 CR.4 (JGK), 1998 WL 598098, at *1 (S.D.N.Y Sept. 8, 1998))); United States v. Moore, No. 97C17181, 1998 WL 778073, at *5 (N.D. Ill. Nov. 2, 1998) (finding Singleton I "unhelpful" because "[n]o other jurisdiction has adopted its holding" and "the reasoning of Singleton $[\mathrm{I}]$. . . is contrary to the Seventh Circuit decision of United States v. Barrett, 505 F.2d 1091 (7th Cir. 1975), a fact the Tenth Circuit acknowledged"); Nero v. United States, Nos. CIV.A. 97-2721, CRIM. 91-321-02, 1998 WL 744031, at*1 (E.D. Pa. Oct. 23, 1998) (citing other recent district court cases and holding that "the short answer is that the promise or prospect of a $\S 5 \mathrm{~K} 1.1$ motion in return for testimony which the government deems to be truthful and of substantial assistance does not violate the bribery statute or otherwise entitle defendant to set aside his conviction or sentence"); United States v. Nieves, No. 3:97CA238 (AHN), 1998 WL 740835, at *1 (D. Conn. Oct. 13, 1998) (citing the historical common law argument of United States v. Barbaro, No. 98CR.412 (JFK), 1998 WL 556152, at *3 (S.D.N.Y. Sept. 1, 1998), that the practice of offering leniency in exchange for cooperation originated with English common law and has been recognized in the United States since that time, as well as the argument that the government, if not specifically included in the scope of a statute, is deemed excluded); United States v. Hammer, 25 F. Supp. 2d 518, 535 (M.D. Pa. 1998) (citing the legislative history of $\S 201$ and other district court cases disagreeing with Singleton I as well as finding that that decision was "an extreme and radical departure from history, practice, and established law[,] ... mak[ing] a criminal out of nearly every federal prosecutor-and accomplices out of district judges... [and] suppress[ing] highly relevant evidence and crippl[ing] enforcement of federal criminal law"); United States v. Laureano, No. 97CR.0741 (HB), 1998 WL 696006, at *1 (S.D.N.Y. Oct. 7, 1998) (citing Barbaro, 1998 WL 556152, at *3; Szur, 1998 WL 661484, at *1; United States v. Arana, No. 95-CR-80272, 1998 WL 420673 (E.D. Mich. July 24, 1998); Guillaume, 1998 WL 462199); United States v. Gabourel, 9 F. Supp. 2d 1246, 1247 (D. Colo. 1998) (adopting the reasoning in United States v. Dunlap, 17 F. Supp. 2d 1183 (D. Colo. 1998)); United States v. Eisenhardt, 10 F. Supp. 2d 521, 521 (D. Md. 1998).

26. See New York State Conference of Blue Cross \& Blue Shield Plans v. Travelers Ins. Co., 514 U.S. 645, 655 (1995) (stressing that the Court "begin[s] as [it] do[es] in any exercise of statutory construction with the text of the provision in question, and move[s] on, as need be, to the structure and purpose of the Act in which it occurs"); Chapman v. Houston Welfare Rights Org., 441 U.S. 600, 608 (1979) ("As in all cases of statutory construction, our task is to interpret the words of these statutes in light of the purposes Congress sought to serve."). 


\section{The LANGUAGE AND LegislatiVE History OF 18 U.S.C. $\S$ 201(C)(2)}

Subsection 201(c)(2) was enacted in substantially its current form over thirty-five years ago. ${ }^{27}$ Yet, no conflict regarding the scope of the statute and no body of judicial interpretation of subsection 201(c)(2) existed until Singleton I. To ascertain the meaning and proper application of the statute, one must first examine its text, considering also the intent of the Congress that crafted the law more than three decades ago.

\section{A. The Language and Plain Meaning of Subsection 201(c)(2)}

Section 201 is divided into two sections, one that prohibits bribery and the other gratuity. ${ }^{28}$ Subsection $201($ b), the bribery provision, makes it illegal to offer something of value to a public official or to a witness with intent to corrupt that witness's testimony. Subsection 201(c)(2), the gratuity provision, is similar to subsection 201(b), but it does not require that an offender intend to corrupt the testimony of the witness. Subsection 201(c)(2) provides:

Whoever ... directly or indirectly, gives, offers or promises anything of value to any person, for or because of the testimony under oath or affirmation given or to be given by such person as a witness upon a trial, hearing, or other proceeding, before any court, any committee of either House or both Houses of Congress, or any agency, commission, or officer authorized by the laws of the United States to hear evidence or take testimony, or for or because of such person's absence therefrom; ... shall be fined under this title or imprisoned for not more than two years, or both. ${ }^{29}$

The U.S. Supreme Court has stated that, when interpreting a statute, the clear and plain meaning of the text should be controlling unless there is an ambiguity that requires examination of the statute's legislative history for clarification. ${ }^{30}$ On its face, the language of sub-

\footnotetext{
27. See Pub. L. No. 87-849, § 1(a), 76 Stat. 1119 (1962).

28. See 18 U.S.C. $\$ 201$ (b)-(c) (1994).

29. Id. $\S 201(\mathrm{c})(2)$.

30. See Salinas v. United States, 522 U.S. 52, 57 (1997) (“Only the most extraordinary showing of contrary intentions in the legislative history will justify a departure from [plain] language." (internal quotation marks omitted)). Over 150 years ago, the Supreme Court stated this principle clearly:

[W] here the words of a law, treaty, or contract, have a plain and obvious meaning, all construction, in hostility with such meaning, is excluded. This is a maxim of law, and a
} 
section 201(c)(2) seems to apply to the government and its agents and therefore to proscribe government officials from exchanging plea bargains for testimony. ${ }^{31}$ Subsection 201(c)(2) uses the word "whoever," one of the most inclusive terms Congress could have used in establishing the set of entities to which the statute applies.

In Singleton II, however, Judge Porfilio, writing for the majority, found that the dictionary definition of "whoever" does not include the government. ${ }^{32}$ Judge Porfilio asserted that, under its "common meaning," the term "whoever" refers to people. ${ }^{33}$ Judge Porfilio reasoned that the legislature would have used the impersonal "whatever," in addition to "whoever," if it had meant to include the government and other entities within the gratuity statute. ${ }^{34}$ Since Congress used only "whoever," the Singleton II court found that "construing 'whoever' to include the government [would be] semantically anomalous." 35 Finding that the United States as an entity includes the federal prosecutors who act as its voice in federal courts, the court further held that federal prosecutors are not included in the definition of "whoever" in subsection 201(c)(2).

The Singleton II majority's restrictive interpretation of "whoever" was not satisfactory to all, however, as Judge Kelly, author of the majority opinion in Singleton I, made clear in a dissenting opinion. In his dissent, Judge Kelly argued that '[t]extually, 'whoever' clearly connotes more than a being and in fact denotes inanimate entities. The Dictionary Act, 1 U.S.C. $\S 1$, definition of 'whoever' includes, but is not limited to, corporations, companies, associations,

dictate of common sense; for were a different rule to be admitted, no man, however cautious and intelligent, could safely estimate the extent of his engagements, or rest upon his own understanding of a law, until a judicial construction of those instruments had been obtained.

Green v. Biddle, 21 U.S. (8 Wheat.) 1, $89-90$ (1821); accord Holloway v. United States, 119 S. Ct. 966 (1999) (stating that "we typically begin the task of statutory construction by focusing on the words that the drafters have chosen").

31. "Whoever" appears to be an inclusive term, which would generally indicate that all persons and entities capable of so acting are included within its scope. See United States v. Lowery, 15 F. Supp. 2d 1348, 1352 (S.D. Fla. 1998) (finding "whoever" to be a "seemingly unlimited statutory class").

32. See Singleton II, 165 F.3d 1297, 1299-302 (10th Cir.), cert. denied, 119 S. Ct. 2371 (1999).

33. See id. at 1300 .

34. See id. (reasoning that "[t]he word 'whatever' is used commonly to refer to an inanimate object").

35. Id.

36. See id. 
firms, partnerships, societies, and joint stock companies-all inanimate entities." 37

Subsections surrounding 201(c)(2) provide contextual guidance in determining the proper interpretation of the gratuity statute. ${ }^{38}$ Perhaps most important, subsection 201(c) is written as a single sentence with three subsections, all of which are directed to "whoever," and all of which come with one stated punishment of a fine or imprisonment. ${ }^{39}$ Subsection 201(c)(1) provides a limitation upon the word "whoever": "otherwise than as provided by law for the proper discharge of official duty."

This limitation in subsection 201(c)(1) is noticeably absent from subsection 201(c)(2), where "whoever" is not limited in any way. Congress's explicit exclusion of government officials from subsection 201(c)(1) appears to indicate that it did not intend to exclude gov-

37. Id. at 1310 (Kelly, J., dissenting).

38. The proper meaning of statutory language must be determined by considering the context in which the words are written. See, e.g., Textron Lycoming Reciprocating Engine Div., Avco Corp. v. UAW, 523 U.S. 653, 657 (1998); Gustafson v. Alloyd Co., 513 U.S. 561, 575 (1995); United Savings Ass'n v. Timbers of Inwood Forest Assocs., 484 U.S. 365, 371 (1988).

39. The text of section 201 (c) reads as follows:

Whoever-

(1) otherwise than as provided by law for the proper discharge of official duty-

(A) directly or indirectly gives, offers, or promises anything of value to any public official, former public official, or person selected to be a public official, for or because of any official act performed or to be performed by such public official, former public official, or person selected to be a public official; or

(B) being a public official, former public official, or person selected to be a public official, otherwise than as provided by law for the proper discharge of official duty, directly or indirectly demands, seeks, receives, accepts, or agrees to receive or accept anything of value personally for or because of any official act performed or to be performed by such official or person;

(2) directly or indirectly, gives, offers or promises anything of value to any person, for or because of the testimony under oath or affirmation given or to be given by such person as a witness upon a trial, hearing, or other proceeding, before any court, any committee of either House or both Houses of Congress, or any agency, commission, or officer authorized by the laws of the United States to hear evidence or take testimony, or for or because of such person's absence therefrom;

(3) directly or indirectly, demands, seeks, receives, accepts, or agrees to receive or accept anything of value personally for or because of the testimony under oath or affirmation given or to be given by such person as a witness upon any such trial, hearing, or other proceeding, or for or because of such person's absence therefrom;

shall be fined under this title or imprisoned for not more than two years, or both.

18 U.S.C. $\S 201$ (c) (1994).

40. Id. § 201(c)(1). 
ernment officials from subsection 201(c)(2). Even more clearly, subsection 201(c)(1)(B) applies only to "a public official, former public official, or person selected to be a public official." possible for Congress to limit the term "whoever" in subsection 201(c)(1)(B) to include only government officials if the term did not include government officials in the first place, as the Singleton II court held. Thus, the context of subsection 201(c)(2) supports a reading of the gratuity statute that includes government officials within the scope of "whoever."

The language of subsection 201(c)(2), examined both in isolation and in the context of surrounding sections, seems relatively straightforward: no one may offer anything of value to any witness in exchange for her testimony, except for witness fees and expenses specifically allowed under subsection $201(\mathrm{~d}){ }^{42}$ A reasonable reading of subsection 201(c)(2), given its language and context, indicates that the statute applies to federal prosecutors because the term "whoever" is broad enough to include the government and its agents and there is nothing in the language of subsection 201(c)(2) to limit the application of "whoever."

\section{B. The Legislative History of Subsection 201(c)(2)}

Courts generally refuse to consult the legislative history for additional help in statutory interpretation except in cases such as this, where the meaning of statutory language is disputed. ${ }^{43}$ Unfortunately, the limited legislative history of subsection 201(c)(2) contains little discussion of the statute's scope.

\footnotetext{
41. Id. $\S 201(\mathrm{c})(1)(\mathrm{B})$.

42. Section 201(d) establishes limited payments that may be made to or received by witnesses:

Paragraphs (3) and (4) of subsection (b) and paragraphs (2) and (3) of subsection (c) shall not be construed to prohibit the payment or receipt of witness fees provided by law, or the payment, by the party upon whose behalf a witness is called and receipt by a witness, of the reasonable cost of travel and subsistence incurred and the reasonable value of time lost in attendance at any such trial, hearing, or proceeding, or in the case of expert witnesses, a reasonable fee for time spent in the preparation of such opinion, and in such appearing and testifying. Id. $\$ 201(\mathrm{~d})$.

43. See Salinas v. United States, 522 U.S. 52, 57-58 (1997) ("Only the most extraordinary showing of contrary intentions in the legislative history will justify a departure from that language.").
} 
Congress enacted section 201 to deter corruption in the government and to prevent possible sources of such corruption. ${ }^{44}$ The statute as a whole addresses bribery, gratuity, graft, and conflicts of interest with regard to government employees in all branches. ${ }^{45}$ In a Senate Report reacting favorably on the statute, the Committee on the Judiciary recognized the "necessity for maintaining high ethical standards of behavior in the Government." in that endeavor by regulating governmental behavior in dealings with private citizens and business entities. ${ }^{47}$ Given that the statute, in general, is directed at government officials and their behavior, one can reasonably infer that Congress intended subsection 201(c)(2) to apply to the government as well.

When section 201 was enacted, it replaced several existing bribery statutes with "a single comprehensive section of the Criminal Code." ${ }^{48}$ Arguing in support of section 201, the Senate Committee on the Judiciary declared that " $[\mathrm{t}]$ his consolidation would make no significant changes of substance and, more particularly, would not restrict the broad scope of the present bribery statutes as construed by the courts. ${ }^{49}$ Furthermore, in discussing sections 201(h) and (i), the first of which became subsection 201(c)(2), ${ }^{50}$ the Senate Report of the Committee on the Judiciary stated that "[s]ubsections (h) and (i) ... forbid offers or payments to, and solicitations or receipt by, a witness of anything of value 'for or because of' testimony given or to be given by him. " ${ }^{51}$ This affirmation of the broad applicability of section 201 supports interpreting subsection 201(c)(2) to include plea bargains offered by government officials.

The courts that have examined the scarce legislative history of section 201 have drawn significant conclusions both from what the history includes and what it does not. ${ }^{52}$ The Singleton I court noted "at

\footnotetext{
44. See S. REP. NO. 87-2213 (1962), reprinted in 1962 U.S.C.C.A.N. 3852, 3857.

45. See 18 U.S.C. $\$ 201$ (1994).

46. S. REP. NO. 87-2213, reprinted in 1962 U.S.C.C.A.N. 3852, 3853.

47. See id., reprinted in 1962 U.S.C.C.A.N. at 3853-56.

48. Id., reprinted in 1962 U.S.C.C.A.N. at 3852-53.

49. Id., reprinted in 1962 U.S.C.C.A.N. at 3853.

50. See Singleton I, 144 F.3d 1343, 1356 (10th Cir. 1998).

51. S. REP. NO. 87-2213 (1962), reprinted in 1962 U.S.C.C.A.N. 3852, 3857.

52. Both the Fifth Circuit and the Hawaii district court have found that Congress did not intend the interpretation of $\S 201$ (c)(2) reached in Singleton I. See United States v. Haese, 162 F.3d 359, 367 (5th Cir. 1998), cert. denied, 119 S. Ct. 1795 (1999) (concluding that "Congress did not intend for section 201(c)(2) to be used when prosecutors offer lenity for a witness' truthful testimony"); United States v. Roque-Acosta, 28 F. Supp. 2d 1256, 1257 (D. Haw. 1998) (failing
} 
the outset that $\S 201$ is to be broadly construed to further its legislative purpose of deterring corruption." ${ }^{, 53}$ Additionally, Singleton I found that when Congress reorganized the criminal bribery statute into separate bribery and gratuity provisions, it deleted the scienter requirement from the gratuity section without limiting the scope of its application. ${ }^{54}$ Because the legislative history indicated no intention by Congress to exclude the government from the prohibition of subsection 201(c)(2), Singleton I found that the government should be included. ${ }^{55}$

In United States v. Ware, ${ }^{56}$ the Sixth Circuit also looked to the legislative history in determining the correct meaning of subsection 201(c)(2). ${ }^{57}$ Like the court in Singleton I, the Ware court found little guidance in the limited legislative history on the question of whether the gratuity statute was intended to apply to the government. ${ }^{58}$ Unlike the court in Singleton I, however, the Ware court cited the absence of legislative history regarding the scope of subsection 201(c)(2) as evidence that the statute does not apply to the government. ${ }^{59}$ The Ware court held that " $\mathrm{t}]$ he legislative history is void of any declaration that [subsection 201(c)(2)] was intended to thwart the long-sanctioned prosecutorial prerogative" of making plea bargains with defendants in exchange for testimony. ${ }^{60}$ The Ware court reasoned that since there was no specific indication from Congress that it intended to take away the longstanding authority of prosecutors to exchange plea bargains for testimony, the statute should not be read to do so.

Unfortunately, the legislative history provides limited guidance in interpreting the unclear language of subsection 201(c)(2). Courts have relied on the absence of significant legislative history to argue both for and against including government officials within the gratuity statute. Judges on both sides have reasoned that congressional intent hostile to their positions would have been explicit. Thus, the absence

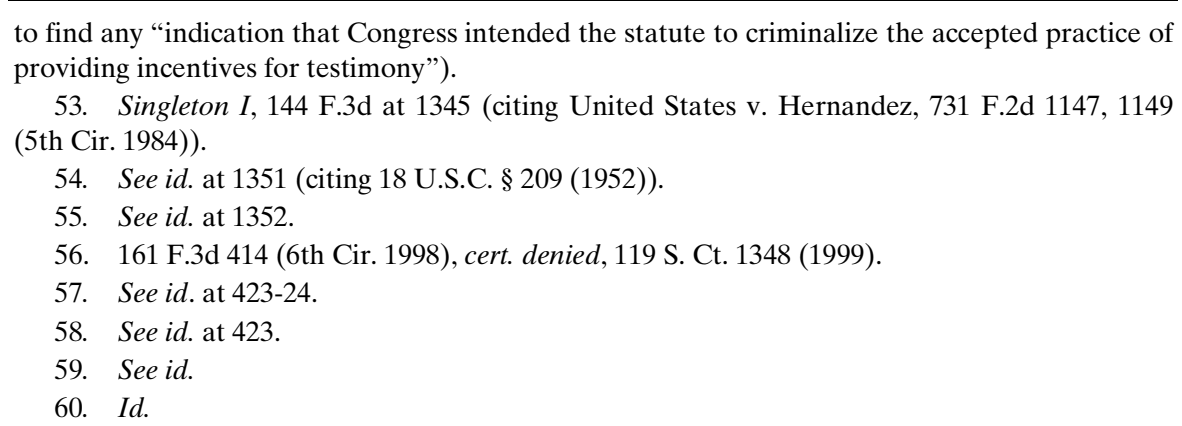


of explicit intent has been used to bolster both inclusion and exclusion of the government from subsection 201(c)(2). Without a single convincing interpretation of subsection201(c)(2), courts are left to examine the evidence, to rely on what they find relevant, and to make independent determinations about the statute's scope.

\section{JUDICIAL INTERPRETATIONS AND THE NARDONE STANDARD}

As discussed above, the scope of subsection 201(c)(2) is not clear from its text or legislative history. Generally, when examination of the statutory text and legislative history are inconclusive, the question of whether a statute applies to the government is examined under the Supreme Court's 1937 decision in Nardone v. United States. ${ }^{61}$ In Nardone, the Supreme Court invoked a canon of statutory construction, based primarily on historical tradition, that a statute is presumed not to apply to the government unless the language of the statute explicitly includes the government.

The Nardone Court identified two classes of cases to which this canon applies. The first class includes those cases in which applying the statute to the government "would deprive the sovereign of a recognized or established prerogative title or interest;" the second is the class of cases in which applying the statute to government officials "would work [an] obvious absurdity." "Although courts interpreting subsection 201(c)(2) have not agreed on whether the Nardone canon applies to cases outside of the two classes specifically addressed by the Nardone Court, ${ }^{63}$ all have used the canon and the Nardone Court's

\footnotetext{
61. 302 U.S. 379 (1937).

62. Id. at 383-84 (citations omitted). The discussion of this canon in the Nardone opinion is brief and provides little guidance for its application.

63. Singleton I found the fact that the Nardone canon had only been applied in two types of cases to be a limiting statement. See Singleton I, 144 F.3d 1343, 1345-46 (10th Cir. 1998) (finding that "[t]he canon applies only to [the] two classes of cases" specifically enumerated in Nardone). Singleton II and Ware did not dispute this finding of the Singleton I court, but found that $\S$ 201(c)(2) fits into both of the classes of cases to which the Nardone Court said the canon applies. See Singleton II, 165 F.3d 1294, 1300-01 (10th Cir.) (en banc), cert. denied, 119 S. Ct. 2371 (1999); Ware, 161 F.3d at 420-22 (6th Cir. 1998), cert denied, 119 S. Ct. 1348 (1999). Many other courts disagreeing with Singleton I also rely on the Nardone canon. See, e.g., United States v. White, 27 F. Supp. 2d 646, 649 (E.D.N.C. 1998) (finding that "[e]ither of these long-recognized exceptions provides a sufficient basis, in this court's view, for its conclusion that the sovereign, and, hence, federal prosecutors, are not prohibited by 18 U.S.C. $\S 201(\mathrm{c})(1)$ from entering into plea agreements with criminal defendants to procure their testimony in other cases"); United States v. Reid, 19 F. Supp. 2d 534, 536-37 (E.D. Va. 1998) (discussing the rule of Nardone as a "canon of statutory construction" and stating that the rule applies to these two types of cases); United States v. Arana, 18 F. Supp. 2d 715, 718 (E.D. Mich. 1998) (applying the same Nardone
} 
discussion of it in determining whether the word "whoever" in subsection 201(c)(2) includes the government. ${ }^{64}$

\section{A. Established Right of the Sovereign}

The first category of cases to which the Nardone canon applies includes those in which application of a statute to the government would impair an established right of the sovereign. ${ }^{65}$ The government is generally not bound by a statute that "tends to restrain or diminish [its] powers, rights, or interests," unless the statute explicitly applies to the government. ${ }^{66}$

In applying this first principle from Nardone, several courts have found that " $\mathrm{t}]$ he prosecutorial prerogative to recommend leniency in exchange for testimony dates back to the common law in England and has been recognized and approved by Congress, the courts, and the Sentencing Commission of the United States. ${ }^{, 67}$ In supporting this finding, the courts have generally relied on the Supreme Court's late nineteenth-century decision in The Whiskey Cases. ${ }^{68}$ In The Whiskey Cases, the Court found that an accomplice cooperating as a witness should have the opportunity to request a pardon from the court and could expect the prosecutor to make a favorable recommendation to

canon but arguing that "[n]othing in that decision or any other Supreme Court decision 'limits' application of the canon to only the two classes of cases mentioned").

64. Although the Nardone canon has been used in the interpretation of $\S 201(\mathrm{c})(2)$, the canon has not been cited or applied often since the Nardone decision was handed down in 1937. According to Westlaw, Nardone has been cited in approximately 260 cases since it was decided in 1937, and more than thirty of those have been since Singleton I. Search of Westlaw, ALLCASES and ALLCASES-OLD databases (Aug. 25, 2000). Very few of the cases citing Nardone before Singleton I cited the case for its rule that statutes do not apply to the sovereign unless they do so explicitly. See, e.g., Shaw v. Library of Congress, 747 F.2d 1469, 1477 (D.C. Cir. 1984); National Association of Letter Carriers v. U.S. Postal Service, 333 F. Supp. 566, 570 (D.D.C. 1971); United States v. Mayo, 47 F. Supp. 552, 556 (N.D. Fla. 1942).

65. See Nardone, 302 U.S. at 383.

66. United States v. Herron, 87 U.S. (20 Wall.) 251, 255 (1873); accord The Dollar Savs. Bank v. United States, 86 U.S. (19 Wall.) 227, 239 (1873) ("It is a familiar principle that the King is not bound by any act of Parliament unless he be named therein by special and particular words."); Singleton II, 165 F.3d at 1302 (speculating that "if Congress had intended that section 201(c)(2) overturn this ingrained aspect of American legal culture, it would have done so in clear, unmistakable, and unarguable language").

67. Ware, 161 F.3d at 419 (citing The Whiskey Cases, 99 U.S. (9 Otto) 594, 604 (1878)); accord Lisenba v. California, 314 U.S. 219, 227 (1941); Benson v. United States, 146 U.S. 325, 33337 (1892); The Whiskey Cases, 99 U.S. (9 Otto) at 599-600); Singleton II, 165 F.3d at 1301 (citing Hoffa v. United States, 385 U.S. 293, 310-12 (1966)).

68. 99 U.S. (9 Otto) 594 (1878). 
the court on the accomplice's behalf. ${ }^{69}$ In addition, The Whiskey Cases discussed the long-established English common law principle on which this expectation was based..$^{70}$ Relying on both the holding and the reasoning of The Whiskey Cases, several courts have found that there is an established government right to plea bargain with criminal defendants and that a statute should not be read to limit that right unless the statute expressly applies to the government. ${ }^{71}$

Although The Whiskey Cases did recognize a historical tradition of defendants cooperating with prosecutors in hopes of receiving favorable treatment, The Whiskey Cases do not actually establish that prosecutors may directly exchange leniency for testimony. Instead, The Whiskey Cases indicates that a cooperating defendant has the right to seek a pardon or leniency and that the defendant should expect that his cooperation in the prosecution will justify receiving it. In the contemporary legal system this relationship is reflected in the Sentencing Guidelines, which enable trial courts to consider whether a defendant-witness has provided "substantial assistance" in a criminal prosecution sufficient to justify reducing her sentence. ${ }^{72}$ The Sentencing Guidelines do not require that a cooperating defendant's "substantial assistance" be predicated on a promise or agreement with the prosecution; instead, there is a general expectation that assistance provided voluntarily by a defendant will be considered favorably by the court even in the absence of such an agreement.

Lower federal courts have argued that the Supreme Court has validated the propriety of agreements similar to the one at issue in the Singleton cases. ${ }^{73}$ In the cases commonly cited for this proposition, the Supreme Court implicitly accepted the validity of testimony obtained through plea bargaining by admitting such testimony as evidence. ${ }^{74}$

69. See id. at 604. The district courts that have reached this conclusion have also relied on The Whiskey Cases. See, e.g., United States v. Abraham, 29 F. Supp. 2d 206, 212 (D.N.J. 1998); United States v. Barbaro, No. 98 CR. 412 (JFK), 1998 WL 556152, at *3 (S.D.N.Y. Sept. 1, 1998); United States v. Juncal, No. 98 CR. 1162 (JFK), 1998 WL 525800, at *1 (S.D.N.Y. Aug. 20, 1998); United States v. Reid, 19 F. Supp. 2d 534, 536 (E.D. Va. 1998).

70. See The Whiskey Cases, (9 Otto) 99 U.S. at 599-605.

71. See United States v. Condon, 170 F.3d 687, 689 (7th Cir. 1999); United States v. Ramsey, 165 F.3d 980, 988 (D.C. Cir. 1999); Ware, 161 F.3d at 419.

72. 18 U.S.C. $\$ 3553(\mathrm{e})(1994)$.

73. See, e.g., United States v. Hunte, No. 97-1987, 1999 WL 649627, at *2 (3d Cir. Aug. 26, 1999); Ramsey, 165 F.3d at 988; Ware, 161 F.3d at 420.

74. See Delaware v. Van Arsdall, 475 U.S. 673, 674-79 (1986) (finding that, for purposes of challenging credibility, the defendant was entitled to cross-examine a witness about an alleged agreement reached between the witness and the prosecutor without directly considering the va- 
The parties in these cases, however, did not question, and the Court did not directly consider, whether those plea agreements were valid. ${ }^{75}$

In Brady v. United States, ${ }^{76}$ for example, the defendant argued that the plea agreement he reached with the government was involuntary and therefore invalid. ${ }^{77}$ The Supreme Court held that Brady's plea was voluntary, finding that it might have been motivated by the recognition that pleading guilty would result in a lesser sentence under the statute than the defendant would risk at trial, where his codefendant, who had already entered a plea agreement with the prosecution, might testify against him. ${ }^{78}$ Although the Brady Court acknowledged that the co-defendant could testify against Brady, the Court did not discuss the circumstances under which the codefendant's testimony became available. ${ }^{79}$ Still, the Court's acknowledgment of the co-defendant as a potential witness, without questioning the validity of the plea agreement that made him available to testify, provides at least implicit approval of such agreements. Relying on cases such as Brady and on the common law tradition of exchanging plea bargains for testimony, ${ }^{80}$ the Ware court found that inter-

lidity of the agreement between the prosecutor and the witness); Giglio v. United States, 405 U.S. 150, 154-55 (1972) (holding that any evidence of an understanding between the prosecution and the co-defendant must be disclosed because it could affect the credibility of the witness, but not examining directly whether the prosecution had the authority to enter into such an agreement); see also Roberts v. United States, 445 U.S. 552, 557-58 (1980) (finding that every citizen has a common law and statutory responsibility to participate in the enforcement of the law, regardless of whether that person faces criminal conspiracy charges).

75. See Van Arsdall, 475 U.S. at 674-79; Giglio, 405 U.S. at 154-55.

76. 397 U.S. 742 (1970).

77. See id. at 743 .

78. See id. at 758.

79. The only mention of testimony in the case is a reference to Brady's co-defendant who, having entered a guilty plea, was "available to testify" against Brady. Id. at 743.

80. The circuit court opinions cited by United States v. Ware, 161 F.3d 414, 421 (6th Cir. 1988), cert. denied, 119 S. Ct. 1348 (1999), support the longstanding existence of a government right to plea bargain with defendants in exchange for testimony. See United States v. CervantesPacheco, 826 F.2d 310, 315 (5th Cir. 1987); United States v. Gomez, 810 F.2d 947, 956 (10th Cir. 1987); United States v. Dailey, 759 F.2d 192, 196 (1st Cir. 1985) ("Long ago the courts rejected the notion that the testimony of co-defendants and other interested witnesses was so likely to be unreliable that it should be excluded.”); United States v. Kimble, 719 F.2d 1253 (5th Cir. 1983); United States v. McCallie, 554 F.2d 770, 772 (6th Cir. 1977); United States v. Barrett, 505 F.2d 1091, 1102 (7th Cir. 1974) ("If the government can excuse criminal or civil liability in settling a criminal case, surely it can use that power of compromise to obtain guilty pleas or to procure testimony in other proceedings."). Courts have also found judicial precedent persuasive in their arguments for a government exception to $\S 201(\mathrm{c})(2)$. See United States v. Abraham, 29 F. Supp. 2d 206, 212 (D.N.J. 1998) ("[E]very federal court of appeals with jurisdiction over criminal cases has allowed testimony by cooperating witnesses in return for sentencing or financial 
preting the gratuity statute to prohibit such agreements would take away an established right of the sovereign. ${ }^{81}$ Since the Nardone canon permits statutory limitation of established sovereign rights only by statutes that explicitly apply to the government, ${ }^{82}$ the courts have found that subsection 201(c)(2) implicitly excludes the government.

The Singleton I court found that subsection 201(c)(2) applies to the government regardless of whether exchanging plea bargains for testimony is an established prosecutorial prerogative. In reaching this conclusion, the Singleton I court relied on two exceptions that the Nardone Court established regarding its rule that statutes should not be interpreted as limiting established rights of the sovereign. ${ }^{83}$ First, Nardone indicates that a statute that does not limit established rights of the government itself might still apply to limit the actions of government agents. ${ }^{84}$ Second, Nardone says that the canon of governmental exclusion from statutes that would infringe on established sovereign rights does not exclude the government from statutes intended to prevent public injury or wrongdoing. ${ }^{85}$

Singleton I found that subsection 201(c)(2) fits within the first exception to the Nardone canon because it applies to prosecutors rather than to the government itself, limiting the "way in which [those] agent[s] carr[y] out the government's interests." that the gratuity statute does not prevent the government from charging, trying, and punishing criminals; it only serves to limit the means government agents may employ in doing so.

Singleton $I$ also found that subsection 201(c)(2) falls under the second exception to the Nardone canon and thus should apply to the government as well as to government agents, because the statute's "purpose is to prevent fraud, injury, or wrong." $"$ The Singleton I court also determined that subsection 201(c)(2) meets the second exception

\footnotetext{
considerations."); United States v. Reid, 19 F. Supp. 2d 534, 537 (E.D. Va. 1998) (“[T]here is an endless number of federal cases among the Circuits in favor of plea agreements.").

81. See Ware, 161 F.3d at 421.

82. See Nardone v. United States, 302 U.S. 379, 383 (1937).

83. See Singleton I, 144 F.3d 1343, 1346 (10th Cir. 1998).

84. See Nardone, 302 U.S. at 383 ("The rule of exclusion of the sovereign is less stringently applied where the operation of the law is upon the agents or servants of the government rather than on the sovereign itself.").

85. See id. at 384 ("[T]he sovereign is embraced by general words of a statute intended to prevent injury and wrong.").

86. Singleton I, 144 F.3d at 1346.

87. Id. at 1346 (citing Nardone, 302 U.S. at 384; United States v. Herron, 87 U.S. (20 Wall.) 251, 255-56 (1873)).
} 
to the Nardone canon because "[t]he anti-gratuity provision ... indicates Congress's belief that justice is undermined by giving, offering, or promising anything of value for testimony." ${ }^{, 8}$ The court noted that the legislative history of subsection 201(c)(2) showed a concern with just such corruption. ${ }^{89}$ As a result, Singleton I found that the Nardone canon does not work to exclude the government from subsection 201(c)(2). ${ }^{90}$

Whether the government has an established right to exchange offers of leniency for testimony from criminal defendants, the Supreme Court has acknowledged the practice in the course of several decisions and has not condemned such agreements. It is unclear whether this indirect precedent is sufficient to show an established government right under Nardone, but it does provide some basis for the argument. As the Singleton I court demonstrated, however, strong arguments can be made that subsection 201(c)(2) falls within one or both of the exceptions to the first class of cases covered by the Nardone canon, suggesting that the government and its agents should be included under the statute.

\section{B. Inclusion Works an Absurdity}

Even if common law tradition and arguably supportive case law do not establish a right of the government or its officers to exchange plea bargains for testimony, many courts considering the issue have found that including the government within the scope of subsection 201(c)(2) is not permissible because inclusion would work an obvious absurdity, the second category to which the Nardone canon applies. ${ }^{91}$

\section{Id.}

89. See supra Part II.B.

90. See Singleton I, 144 F.3d at 1346 ("Because $§ 201$ (c)(2) addresses what Congress perceived to be a wrong, and operates to prevent fraud upon the federal courts in the form of inherently unreliable testimony, the proscription of $\S 201$ (c)(2) must apply to the government."); see also United States v. Lowery, 15 F. Supp. 2d 1348, 1353 (S.D. Fla. 1998) ("Even assuming that the Executive Branch has a recognized or established interest in securing the cooperation of defendants, the Executive Branch cannot establish that Section 201(c)(2) operates on the Executive Branch, as opposed to individual federal officers.").

91. See United States v. Ware, 161 F.3d 414, 421 (6th Cir. 1988), cert. denied, 119 S. Ct. 1348 (1999); United States v. Abraham, 29 F. Supp. 2d 206, 211 (D.N.J. 1998) (“[A] reading of $\S$ 201(c)(2) as given by the Singleton panel would lead to absurd results . . . Courts may ignore the plain meaning of the words of the statute in order to avoid the absurd result that would follow the prohibition of all such testimony in criminal and civil enforcement cases."); United States v. White, 27 F. Supp. 2d 646, 649 (E.D.N.C. 1998) (“[A]pplying § 201(c)(2) to government plea agreements entered to procure future testimony would 'work obvious absurdity' because without such testimony, the government would be unable to ... effectively proceed in the thou- 
A classic example of this second class of cases is speed limits. Requiring police officers in pursuit of fleeing suspects or rushing to the scene of a crime to abide by speed limits would be an absurd impediment to the carrying out of their official responsibilities.

Singleton II found that it would be "absurd" to believe that Congress "intended to subject the United States to the provisions of $\S$ 201(c)(2), and, consequently, like any other violator, to criminal prosecution. " ${ }^{22}$ In contrast, Singleton I found that in a law-abiding society, government officials are subject to the same laws as general citizens. ${ }^{93}$ Because the creation and limits of government authority have always been established by written law, the Singleton I court found that "the statute's application to government officials, far from being absurd, is at the center of our legal tradition." ${ }^{94}$

In addition to this general argument over whether subsection 201(c)(2) should fall into the second class of cases subject to the Nardone canon, some courts have held that conflicts between the Singleton I reading of the gratuity statute and other federal provisions-the Federal Rules of Criminal Procedure, the United States Sentencing Guidelines, and the federal immunity statute-reveal the absurdity of interpreting subsection 201(c)(2) as prohibiting government officials from making plea bargains in exchange for testimony. ${ }^{95}$ These laws

sands of cases each year in which it relies on witnesses who testify in return for leniency." (quoting Nardone, 302 U.S. at 384)); United States v. Reid, 19 F. Supp. 2d 534, 537 (E.D. Va. 1998) ("[P]rohibit[ing] prosecutors from making promises in exchange for testimony works an 'absurd' result where crimes go unresolved because of worries about testimony that may be questionable, even though the system already has built-in safeguards concerning questionable testimony by interested witnesses."); United States v. Arana, 18 F. Supp. 2d 715, 718 (E.D. Mich. 1998) ("[T]his case fits squarely within the second class of cases [of Nardone] - construing Section 201(c)(2) as argued by Defendants would create an absurdity if applied to federal prosecutors in their negotiation and execution of plea agreements.").

92. Singleton II, 165 F.3d 1297, 1300 (10th Cir.), cert. denied, 119 S. Ct. 2371 (1999).

93. See Singleton I, 144 F.3d at 1347.

94. Id. at 1347-48.

95. See Ware, 161 F.3d at 421-22 ("To apply $\S 201$ (c)(2) to the government ... works the further absurdity of making criminal that which is explicitly permitted pursuant to the United States Code as well as the Sentencing Guidelines.”); United States v. Roque-Acosta, 28 F. Supp. 2d 1256, 1257 (D. Haw. 1998) (finding the inclusive interpretation of $\S 201$ (c)(2) to be in conflict with both 18 U.S.C. $\$ 3553$ (e) (1994), a Sentencing Guideline authorizing sentence reductions in exchange for "substantial assistance in the investigation or prosecution of another person," and 18 U.S.C. $\S \S 6001-05$ (1994), statutes allowing grants of immunity to witnesses in exchange for testimony); Abraham, 29 F. Supp. 2d at 213 (holding that Singleton I's interpretation of $\S$ 201(c)(2) conflicts with Federal Rule of Criminal Procedure 11 and Federal Rule of Evidence 410 (both of which allow plea bargaining), the Sentencing Reform Act of 1984, which authorizes reduced sentencing in exchange for cooperation and assistance, 18 U.S.C. $\S \S 6001-05$ (1994), and 18 U.S.C. $\S 3521(\mathrm{~b})(1)$, the Witness Relocation and Protection Act, which authorizes payment 
and rules have been interpreted by some courts as permitting or encouraging federal prosecutors to plea bargain with defendants in exchange for truthful testimony. Courts that have interpreted the Federal Rules of Criminal Procedure, the United States Sentencing Guidelines, and the federal immunity statute as condoning the power of federal prosecutors to plea bargain have held that interpreting subsection 201(c)(2) in a way that would prohibit these agreements would create the absurdity of criminalizing actions that other rules and laws authorize.

Authority for federal prosecutors to exchange leniency for truthful testimony can be found in Rule 11 of the Federal Rules of Criminal Procedure. Rule 11 sets forth the guidelines for criminal pleas, and subsection 11(e) specifically addresses the procedure for making a plea agreement. ${ }^{96}$ Under Rule $11(\mathrm{e})(1)$, an agreement may be made between a prosecutor and a defendant where the defendant agrees to enter "a plea of guilty or nolo contendere to a charged offense, or to a lesser or related offense," and the prosecutor promises to afford leniency to the defendant in return. ${ }^{97}$ Because defendants must enter their pleas in open court, pleas may be considered testimony. Thus, a prosecutor making a plea agreement may be said to have exchanged leniency for the defendant's testimony. By this reasoning, a plea agreement expressly permitted under Rule 11(e) would violate the Singleton I interpretation of subsection 201(c)(2).

The Federal Sentencing Guidelines can also be read as authorizing prosecutors to enter into plea bargains in exchange for testi-

\footnotetext{
of living and housing expenses to witnesses in exchange for testimony); United States v. Dunlap, 17 F. Supp. 2d 1183, 1185-87 (D. Colo. 1998) (finding that the broader Singleton I interpretation would conflict with Federal Rule of Criminal Procedure 11(e), 18 U.S.C. § 3553 (1994), 18 U.S.C. $\S \S 6001-05$, and 18 U.S.C. $\S 3521(\mathrm{~b})(1)-(\mathrm{d})(1)(\mathrm{A})$ ); United States v. Guillaume, 13 F. Supp. 2d 1331, 1333-34 (S.D. Fla. 1998) (finding conflicts with 18 U.S.C. § 3553(e), 28 U.S.C. § 994(n) (1994), a Sentencing Guideline instruction to ensure that substantial assistance would result in a reduced sentence, Federal Rule of Criminal Procedure 35(b), which provides for reductions after sentencing to reflect assistance subsequent to sentence imposition, U.S.S.G. $\S$ $5 \mathrm{~K} 1.1$, which provides for downward departures from the sentencing guidelines if the defendant provided reliable and helpful testimony, and 18 U.S.C. $\S \S 6001-05) ;$ Arana, 18 F. Supp. 2d at 718-19 (finding conflicts with 18 U.S.C. $§ \$ 6001-05,18$ U.S.C. $§ 3553(\mathrm{e})$, and U.S.S.G. § 5K1.1).

96. See FED. R. CRIM. P. 11(e).

97. Id. Under Rule 11(e)(1), the prosecutor may: (1) move to dismiss other charges against the defendant; (2) make a sentencing recommendation or agree not to oppose the defendant's sentencing request; or (3) agree with the defendant on the appropriate sentence. See id.
} 
mony. ${ }^{98}$ Under 18 U.S.C. $§ 3553(\mathrm{e})$, a trial court may impose a sentence less than prescribed in the Sentencing Guidelines to "reflect a defendant's substantial assistance in the investigation or prosecution of another person who has committed an offense." interpreted "substantial assistance" to include testifying against another criminal defendant and have thus found that subsections 3553(e) and 201(c)(2) would directly conflict if the gratuity statute were applied to the government. ${ }^{100}$ In addition, section 994 of the Sentencing Reform Act directs the Sentencing Commission to set sentence guidelines that "reflect the general appropriateness of imposing a lower sentence ... to take into account a defendant's substantial assistance in the investigation or prosecution of another person who has committed an offense." ${ }^{, 101}$ Again, some courts have found that applying subsection 201(c)(2) to the government would conflict with this statute, indicating the absurdity of this interpretation of the gratuity statute. $^{102}$

Finally, many courts have found that the federal immunity statute, ${ }^{103}$ which authorizes federal prosecutors to make agreements with defendants, would be invalid under the Singleton I interpretation of subsection 201(c)(2). ${ }^{104}$ The federal immunity statute allows prosecutors to offer immunity to witnesses in order to induce them to testify in criminal proceedings. Courts have found that this explicit authorization of exchanging leniency for testimony conflicts with Singleton

98. See 18 U.S.C. $§ 3553($ e) (1994); Ware, 161 F.3d at 421-22; Roque-Acosta, 28 F. Supp. 2d at 1257-58; Arana, 18 F. Supp. 2d at 718-19; Dunlap, 17 F. Supp. 2d at 1186-87; Guillaume, 13 F. Supp. $2 \mathrm{~d}$ at $1333-34$.

99. 18 U.S.C. $\$ 3553(\mathrm{e})$.

100. See Roque-Acosta, 28 F. Supp. 2d at 1257; Arana, 18 F. Supp. 2d at 718-19; Dunlap, 17 F. Supp. 2d at 1186-87; Guillaume, 13 F. Supp. $2 \mathrm{~d}$ at 1333-34.

101. 28 U.S.C. $\$ 994(n)$ (1994).

102. See Ware, 161 F.3d at 422 ("To apply $\S 201$ (c)(2) to the government ... works the further absurdity of making criminal that which is explicitly permitted pursuant to other sections of the United States Code...."); Guillaume, 13 F. Supp. 2d at 1333-34 ("[T]he application of $\$ 201(c)(3)$ to the government would ... necessitate the bizarre conclusion that federal prosecutors routinely violate the law by promising to move to reduce the sentences of defendants in exchange for their testimony.").

103. See 18 U.S.C. $\$ \S 6001-05$ (1994).

104. See Ware, 161 F.3d at 422; United States v. Abraham, 29 F. Supp. 2d 206, 213 (D.N.J. 1998); Roque-Acosta, 28 F. Supp. 2d at 1257; Arana, 18 F. Supp. 2d at 718; Dunlap, 17 F. Supp. 2d at 1187; Guillaume, 13 F. Supp. 2d at 1334. 
I's reading of subsection 201(c)(2). ${ }^{105}$ As the Sixth Circuit reasoned, "there is no purpose for a grant of immunity to a witness except to obtain his testimony. And certainly immunity from prosecution is '[s]omething of value' given 'for or because of the testimony under oath or affirmation.'”

The Singleton I court considered whether interpreting subsection 201(c)(2) to include the government or its officers would work an absurdity by creating conflicts with other statutes and rules that authorize federal prosecutors to enter into plea agreements in exchange for testimony. ${ }^{107}$ Although it did not address Federal Rule of Criminal Procedure 11(e), the Singleton I court did conclude that applying subsection 201(c)(2) to the government and its agents would not conflict with the Sentencing Guidelines or with the federal immunity statute. $^{108}$

The Singleton I court found no conflict between the Sentencing Guidelines and a broad interpretation of subsection 201(c)(2) because "substantial assistance" under the Sentencing Guidelines includes "myriad ways other than by testifying" that a defendant may assist the prosecution and be entitled to a downward departure under the Sentencing Guidelines. ${ }^{109}$ The Singleton I court concluded that the only limit subsection 201(c)(2) placed on a prosecutor's authority to offer leniency for assistance in the prosecution is that "it simply may not attach any promise, offer, or gift to [a witness's] testimony."110 Additionally, according to the Singleton I court, a downward departure is only available after substantial assistance has been given; leniency cannot be part of a deal made between the prosecution and the witness before the witness testifies. ${ }^{111}$

The Singleton I court did not find a conflict between its broad reading of subsection 201(c)(2) and the federal immunity statute, because, according to the court, the two statutes can "operate fully and

105. See Ware, 161 F.3d at 422; Abraham, 29 F. Supp. 2d at 213; Roque-Acosta, 28 F. Supp. 2d at 1257; Arana, 18 F. Supp. 2d at 718; Dunlap, 17 F. Supp. 2d at 1187; Guillaume, 13 F. Supp. $2 \mathrm{~d}$ at 1334 .

106. Ware, 161 F.3d at 422 (quoting 18 U.S.C. $\$ 201$ (c) (1994)).

107. See Singleton I, 144 F.3d 1343, 1354-56 (10th Cir. 1998), rev'd en banc, 165 F.3d 1297 (10th Cir. 1999)

108. See id.

109. Id. at 1355 .

110. Id.

111. See id. 
independently." 112 A court may grant immunity to compel a witness to testify when that witness has refused to do so, but federal prosecutors may not promise immunity to a witness to encourage the witness to testify. The Singleton I court found that "the government does not give immunity directly for the witness's testimony; the government may move the court to grant immunity, which in turn removes the witness's testimonial [Fifth Amendment] privilege so the ordinary compulsion may be brought to bear to require the witness to testify." ${ }^{113}$ The Singleton I court found that its inclusive reading of subsection 201(c)(2) did not conflict with the federal immunity statute, because the power to grant immunity belongs to the court, not to the prosecutor, and because the federal immunity statute contemplates that courts will use immunity not as a bargaining chip to encourage witnesses to testify but as a means of compelling testimony from witnesses who might otherwise assert the Fifth Amendment privilege against self-incrimination. ${ }^{114}$

112. Id. at 1348; accord id. (finding that "together, [the statutes] manifest a Congressional intent to allow testimony obtained by the court's grant of immunity, but to criminalize the gift, offer, or promise of any other thing of value for or because of testimony").

113. Id.

114. A promise from the prosecutor or law enforcement personnel not to prosecute a witness on the basis of information provided by the witness is not the same as a grant of immunity. See 18 U.S.C. $\S \S 6002-6003$ (1994) (authorizing the judge or person presiding over a proceeding to compel the testimony of a witness invoking the Fifth Amendment privilege by issuing an order of immunity prohibiting the government from using the testimony or information against the witness in a criminal proceeding); Rowe v. Griffin, 676 F.2d 524, 527-29 (11th Cir. 1982) (enforcing a promise by law enforcement officers not to prosecute a witness who agreed to testify for the state and finding that the government should be required to honor such promises made by prosecutors and law enforcement officers where the agreement induced the defendant to waive her Fifth Amendment privilege); United States v. Cooke, 650 F. Supp. 991, 993-94 (D. Md. 1987) (distinguishing a grant of immunity from an informal promise by law enforcement personnel not to use statements against a criminal defendant); In re Kelly, 350 F. Supp. 1198, 1199-200 (E.D. Ark. 1972) (distinguishing a grant of immunity from an agreement not to prosecute but finding that where the prosecution has promised not to use testimony provided by another witness against the witness, the witness "receives, in effect, use immunity from prosecution"); see also Robert M. Schoenhaus, Annotation, Prosecutor's Power to Grant Prosecution Witness Immunity from Prosecution, 4 A.L.R.4th 1221 (1981); Jay M. Zitter, Annotation, Enforceability of Agreement by Law Enforcement Officials Not to Prosecute if Accused Would Help in Criminal Investigation or Would Become Witness Against Others, 32 A.L.R.4th 990 (1984). Once immunity has been granted by the court, it is absolute and cannot be qualified or revoked as long as the witness complies with the order to testify with immunity. See 18 U.S.C. $\S 6002$ (stating that once immunity has been granted and the witness testifies as a result of the immunity, "no testimony or other information compelled under the order ... may be used against the witness in any criminal case"); United States v. Balsys, 524 U.S. 666, 681-83 (1998) (finding that the "only condition on the government when it decides to offer immunity in place of the privilege to stay silent [in order to compel testimony] is the requirement to provide an immunity as 
As the preceding discussion makes clear, applying the Nardone canon of statutory construction is complicated and involves a number of difficult interpretive questions. Courts on both sides of the debate have found support in Nardone for their interpretations of subsection 201(c)(2) but have been unable to completely dispel the reasoning of courts that have reached the opposite interpretive conclusion. The disparate applications of the Nardone canon of statutory interpretation to subsection 201(c)(2) can only be resolved through an analysis conducted by the Supreme Court. Since that is unlikely to occur soon, other solutions to this interpretive struggle should be considered.

\section{THE IMBALANCE THAT CONGRESS AND THE COURTS FAILED TO CONSIDER}

Although other circuit courts have followed Singleton II in finding that that subsection 201(c)(2) does not apply to the government or to officers of the government, ${ }^{15}$ it remains unclear whether Singleton I or Singleton II constitutes the correct interpretation of the gratuity statute. Since the courts must interpret subsection 201(c)(2) as it is written, with little guidance from legislative history or rules of statutory construction, debate over the proper interpretation and application of the statute will remain until Congress addresses the source of the problem: the statute's ambiguous text. ${ }^{116}$

broad as the privilege itself" (citing Kastigar v. United States, 406 U.S. 441, 449 (1972))). A promise not to seek charges, while possibly binding on the government as a contractual agreement, may be limited by any number of terms or conditions. See Rowe, 676 F.2d at 527-29 (applying a "contractual analysis" to the issue of whether the defendant complied with the terms of an agreement that promised that no charges would be brought against the defendant if he complied with the agreement); United States v. San Pedro, 781 F. Supp. 761, 763-65 (S.D. Fla. 1991) (considering whether the defendant complied with the conditions and terms of a plea agreement where the government promised to drop two of the three charges against the defendant in exchange for his testimony and cooperation).

115. See United States v. Richardson, No. 98-4139, 1999 WL 686892 (4th Cir. Sept. 3, 1999); United States v. Hunte, No. 97-1987, 1999 WL 649627 (3d Cir. Aug. 26, 1999); United States v. Lara, 181 F.3d 183 (1st Cir. 1999); United States v. Stephenson, 183 F.3d 110 (2d Cir. 1999); United States v. Condon, 170 F.3d 687 (7th Cir. 1999); United States v. Johnson, 169 F.3d 1092 (8th Cir. 1999); United States v. Lowery, 166 F.3d 1119 (11th Cir. 1999); United States v. Ramsey, 165 F.3d 980 (D.C. Cir. 1999); United States v. Haese, 162 F.3d 359 (5th Cir. 1998), cert. denied, 119 S. Ct. 1795 (1999); United States v. Ware, 161 F.3d 414 (6th Cir. 1998), cert. denied, 119 S. Ct. 1348 (1999).

116. See Singleton II, 165 F.3d 1297, 1310 (10th Cir.) (en banc) (Kelly, J., dissenting), cert. denied, 119 S. Ct. 2371 (1999):

This court must perform its constitutional duties and no more. Ours is not to explore the farthest meanings that the term "whoever" can bear so as to effectuate the policy we think best. Our duty is to interpret the plain meaning of the statute. . . If the bal- 
While Congress has the exclusive authority to clarify the language of subsection 201(c)(2), it has not seriously attempted to do so. On July 15, 1998, Senator Leahy of Vermont introduced Senate Bill 2314 proposing to amend 18 U.S.C. $\S 201(\mathrm{c}),{ }^{117}$ but the bill died in the Senate Judiciary Committee. Specifically, Senate Bill 2314 proposed to amend subsection 201(c) to exclude the federal government and government agents from all of its parts. ${ }^{118}$

The lack of action on Senate Bill 2314 may indicate that Congress has decided to leave the interpretation of subsection 201(c)(2) as it currently stands. Since the bill would codify the same government exception from the gratuity statute that the courts have read into the statute, this conclusion seems logical. Because only Congress can finally clarify the proper meaning of this important yet imprecise statute, however, merely presuming congressional intent from Congress's lack of action is not a satisfactory resolution. ${ }^{119}$ Congress should reevaluate the purpose and effect of subsection 201(c)(2) and amend the law to clearly define the authority of the federal government and government agents in making plea bargains with criminal defendants in exchange for testimony.

Congress needs to take two steps in reexamining the proper purpose and application of subsection 201(c)(2). The first step is to evaluate whether allowing prosecutors to offer leniency and other consideration in exchange for testimony meets the interests of public policy. Given the longstanding tradition of this commonly accepted practice in our criminal justice system, the probable conclusion is that public policy favors allowing prosecutors to make such bargains. Second, Congress must consider whether defendants receive a fair trial when prosecutors have the unique ability to offer consideration (with all its attendant advantages) to encourage reluctant witnesses to testify. If public policy demands that we allow prosecutors to make such deals, perhaps fairness dictates that we permit defendants an opportunity to do the same." Only after weighing both policy concerns and

ance struck by $\S 201$ is to be reweighed, that reweighing should be done by the policymaking branch of government-the Congress, and not the courts.

117. See S. 2314, 105th Cong. (1998).

118. See id. $\S 1$.

119. Cf. Morgen A. Sullivan, "A Derelict in the Stream of the Law": Overruling Baseball's Antitrust Exemption, 48 DUKE L.J. 1265, 1276-82 (1999) (explaining why Congress's inaction may not signify congressional acceptance of judicial interpretations in the context of baseball's antitrust exemption). 
defendants' constitutional guarantee of a fair trial can Congress effectively and appropriately resolve the debate that Singleton I initiated.

\section{A. Public Policy Interests in Bargaining for Testimony}

The first step in reconsidering subsection 201(c)(2) is to decide whether it is in the public interest to continue allowing plea bargaining in exchange for testimony. In criminal prosecutions, the government acts on behalf of the people in seeking efficient and effective criminal justice. Many prosecutions depend heavily on the testimony of co-conspirators and accomplices as evidence against the defendant. Prohibiting prosecutors from entering into plea bargains in exchange for testimony would make it much more difficult to prosecute crimes, such as drug trafficking conspiracies, where there are few potential witnesses who were not involved in the criminal activities at some level. ${ }^{120}$ This reality provides a strong public policy justification for continuing to permit prosecutors to make plea agreements that exchange leniency for testimony.

Nevertheless, while offering plea bargains in exchange for testimony may be efficient and effective, investigating and prosecuting crimes is not the only societal concern in the criminal justice system, as Judge Kelly noted in his dissent in Singleton II. ${ }^{121}$ Congress should also consider society's interest in "maintaining the integrity, fairness, and credibility of our system of criminal justice. Criminal judgments are accepted by society at large, and even by individual defendants, only because our system of justice is painstakingly fair." ${ }^{122}$ Thus, Congress must balance the important role played by prosecutorial discretion to plea bargain with society's interest in maintaining a criminal justice system that is fair to defendants.

Criminal defendants who have the opportunity to exchange testimony against another defendant for prosecutorial leniency have an incentive to promise to testify to whatever facts will most help the

120. See Haese, 162 F.3d at 366 ("[F]requently the most knowledgeable witnesses available to testify about criminal activity are other co-conspirators."); United States v. White, 27 F. Supp. 2d 646, 649 (E.D.N.C. 1998) ("[W]ithout such testimony, the government would be unable to enforce drug laws, prosecute organized crime figures under RICO, or otherwise effectively proceed in the thousands of cases each year in which it relies on witnesses who testify in return for leniency.”); United States v. Reid, 19 F. Supp. 2d 534, 537 (E.D. Va. 1998) (“[T]here are situations where those [indicted co-conspirators] may be the only credible witnesses of criminal activity, and, without their testimony, the government would not be able to obtain convictions.").

121. See Singleton II, 165 F.3d at 1309 (Kelly, J., dissenting).

122. Id. 
prosecution's case, truthful or not. ${ }^{123}$ As J. Richard Johnston noted, perhaps it is a fundamental belief in "the prosecutor's 'higher duty' not to merely obtain a conviction, but also to seek justice" that allows us to believe that the government will not take advantage of the ability to make plea agreements in order to induce favorable but untruthful testimony. ${ }^{124}$ Nevertheless, the courts have recognized the substantial risk that a witness will be motivated to lie in order to get a favorable plea bargain from the prosecution. ${ }^{125}$ In United States $v$. Cervantes-Pacheco, ${ }^{126}$ for example, the Fifth Circuit admitted that "[i]t is difficult to imagine a greater motivation to lie than the inducement of a reduced sentence."

Even recognizing these risks, there are persuasive public policy reasons to continue allowing the government to offer leniency to a criminal defendant in exchange for testimony against another criminal defendant. As Senator Leahy argued when introducing Senate Bill 2314, Congress must "insure that prosecutors have the tools they need to do their jobs effectively, and being able to enter into cooperation agreements is critical." 128 Similarly, the Sixth Circuit has noted that "[i]t is an occupational hazard of prosecutors that to prove the guilt of a criminal defendant beyond a reasonable doubt, they often must rely on the testimony of other criminal defendants, many of whom are less than enthusiastic about assisting the prosecution." ${ }^{129}$ Disallowing the exchange of leniency for testimony would limit prosecutors to testimony of other criminal defendants that is "voluntarily provided without hope of benefit to the volunteer, [which]

123. See Justin M. Lungstrum, Note, United States v. Singleton: Bad Law Made in the Name of a Good Cause, 47 U. KAN. L. REV. 749, 766 (1999) (arguing that "it goes without saying that pleasing the prosecutor is in the best interest of the defendant" and that the "unfortunate result is that some cooperators may embellish or outright lie in the name of self-preservation to make their assistance as substantial as possible").

124. J. Richard Johnston, Paying the Witness: Why Is It OK for the Prosecution, but Not the Defense, CRIM. JusT., Winter 1997, at 21, 24.

125. See United States v. McCallie, 554 F.2d 770, $771-72$ (6th Cir. 1977) (“Accomplice testimony, of course, is not barred in criminal prosecutions, although the courts recognize the danger that it may be self-serving and unreliable.").

126. 826 F.2d 310 (5th Cir. 1987).

127. Id. at 315 .

128. 144 CONG. REC. S8248 (1998) (statement of Sen. Leahy).

129. United States v. Ware, 161 F.3d 414, 423 (6th Cir. 1998), cert. denied, 119 S. Ct. 1348 (1999). 
would ... seriously undermine the ability of prosecutors to prosecute. $" 130$

As shown, there are several persuasive public policy justifications that support allowing federal prosecutors to enter into plea agreements that exchange leniency for testimony. These justifications have been at the heart of every opinion disagreeing with the Singleton I interpretation of subsection 201(c)(2), whether they were forcefully articulated or not. Given these policy considerations and the longstanding tradition of prosecutorial plea bargaining, Congress would likely have no difficulty concluding that the practice should be allowed to continue.

\section{B. The Defendant's Right to a Fair Trial}

Although the public interest in an efficient and effective criminal justice system is significant, there is an equally strong interest in ensuring that criminal trials are fair to the defendants. From the reasonable doubt standard to the Miranda warnings, the American criminal justice system has been developed to meet the promise of the Fifth Amendment that every person is entitled to a fair trial. In reconsidering the provisions of subsection 201(c)(2), Congress needs to evaluate whether allowing only the prosecutor in a criminal trial to offer valuable incentives to witnesses is fair to the defendant.

The judicial system has admitted, to some extent, the conflict between the government's interest in a justice system that facilitates conviction of criminals and one that protects a defendant's interest in a fair trial. Recognition of this conflict is evidenced in the procedural rules that have been implemented in an attempt to strike a balance between allowing unrestricted prosecutorial discretion to make plea bargains and protecting the rights of defendants in the criminal judicial process. Prosecutors are currently required to disclose to the defense the details of any plea agreements the prosecutors have entered into in exchange for a witness's testimony. ${ }^{131}$ The defense may crossexamine such witnesses about their plea agreements with the prosecution and may question the effects that the plea bargains have on the

130. Id.; accord United States v. Guillaume, 13 F. Supp. 2d 1331, 1335 (S.D. Fla. 1998) (finding that the plea bargaining process is "a necessary investigatory and prosecutorial activity" and that "[t]he holding of the Singleton $[I]$ panel would dangerously disable the government's investigatory and prosecutorial powers").

131. See Giglio v. United States, 405 U.S. 150, 153-54 (1972). 
credibility of these witnesses' testimony. ${ }^{132}$ The underlying rationale for this approach is that the jury may then evaluate the proper weight to give to a witness's testimony by considering any possible motive the witness would have to be a favorable but untruthful witness for the prosecution. ${ }^{133}$

The disclosure requirement and the right to question prosecution witnesses about plea agreements may provide some protections for a criminal defendant, but they are designed more to prevent prosecutorial witness tampering than to guarantee defendants a fair trial. As Judge Kelly argued in his dissent in Singleton II:

Constitutional law manifests another vital legal tradition which the government's position undercuts-the policy of ensuring a level playing field between the government and defendant in a criminal case. The Supreme Court long ago recognized that impartiality in criminal cases requires that "[b]etween [the accused] and the state the scales are to be evenly held.

Allowing prosecutors to offer something as valuable as personal freedom to potential witnesses in exchange for favorable testimony seems to conflict with the constitutional guarantee of the Fifth Amendment and certainly does not maintain a balanced scale between the parties.

\section{Balancing Fairness and Public Policy by Repealing Subsection 201(c)(2)}

Only a legislative solution, and not a judicial one, can properly balance the public policy interest in allowing prosecutors to plea bargain with witnesses without unfairly tipping the scales against defendants. Congress should repeal subsection 201(c)(2) $)^{135}$ and allow both the prosecution and the defense to offer gratuities, but not bribes, in exchange for witness testimony. Congress should then adopt clear disclosure requirements that require both parties to reveal the existence and extent of the deals they made to encourage witness testimony.

132. See Delaware v. Van Arsdall, 475 U.S. 673, 678-79 (1986).

133. See id. at 679 .

134. Singleton II, 165 F.3d 1297, 1314 (10th Cir.) (en banc), cert. denied, 119 S. Ct. 2371 (1999) (Kelly, J., dissenting) (quoting Hayes v. Missouri, 120 U.S. 68, 70 (1887)).

135. As mentioned in the Introduction to this Note, this suggestion includes the companion statute found in $\S 201(\mathrm{c})(3)$ with regard to accepting such things of value offered in violation of $\S 201(\mathrm{c})(2)$. As they are companion statutes, they should be considered together. 
Subsection 201(c)(2) is not necessary to the legislature's goal of deterring the purchase of false testimony. Subsection 201(b)(3) sets adequate parameters of acceptable behavior for both the prosecution and the defense even in the absence of subsection 201(c)(2). Under subsection 201(b)(3):

Whoever... directly or indirectly, corruptly gives, offers, or promises anything of value to any person, or offers or promises such person to give anything of value to any other person or entity, with intent to influence the testimony under oath or affirmation of such... person as a witness... shall be fined under this title... or imprisoned for not more than fifteen years, or both .... ${ }^{136}$

Thus, if either the prosecution or the defense offers a witness consideration with the intent to gain false testimony, she is in violation of subsection 201(b)(3) and is subject to much more severe penalties than are available under subsection 201(c)(2). ${ }^{137}$ Although repealing subsection 201(c)(2) altogether may make it somewhat more difficult to uncover and prosecute witness tampering, this approach balances the interests of the government in obtaining criminal convictions through the use of co-defendant testimony with the constitutional right of defendants to a fair trial.

The only necessary adjunct to repealing subsection 201(c)(2) is the requirement that the gratuity disclosure requirements currently imposed on federal prosecutors be made equally applicable to defendants. Once subsection 201(c)(2) were repealed, prosecutors and defense attorneys would be free to offer consideration to witnesses in exchange for testimony as long as the offer was not made with intent to corrupt the witness's testimony. The need of prosecutors and defense attorneys alike to maintain witness credibility will work as an inherent deterrent against abuse. If the gratuity offered in exchange for testimony is too great, disclosure of the agreement will hurt the witness's credibility - and therefore the credibility of the party calling the witness.

One of the strengths of repealing subsection 201(c)(2) to resolve the conflict over its interpretation is the simplicity of the approach. Deliberate attempts to induce untruthful testimony would still be illegal under the bribery statute, but the playing field between the prose-

136. 18 U.S.C. $\$ 201$ (b)(3) (1994) (emphasis added).

137. Compare 18 U.S.C. $\S 201($ b)(3), with id. $\S 201$ (c)(2) (providing for up to 15 years of imprisonment and fines in the former, but only up to two years and fines in the latter). 
cution and defense would be leveled. Provided that the consideration offered to a witness in exchange for testimony did not contravene the bribery statute, the offering party simply would be required to disclose the gratuity so that the court and the jury could consider the arrangement in assessing the witness's credibility. The gratuity offered to the witness could include things as simple as a new suit of clothes to wear at the trial or something intangible yet valuable to the witness. Obviously, the most common incentive that defendants could and would offer to potential witnesses would be money. The jury would consider the amount of money given and weigh that factor in determining the credibility of the witness. As long as there is no evidence that the defense attorney is attempting to coerce false testimony, then there would be no criminal act. Witnesses do not always feel motivated to testify by a sense of moral obligation, which is why federal prosecutors offer leniency in exchange for needed testimony. Defense attorneys also need methods for inducing uncooperative witnesses to agree to testify on behalf of their clients. ${ }^{138}$ The defense still may not be able to offer witnesses anything as valuable as reduced criminal charges or sentencing leniency, but this is a better approach than continuing to allow prosecutors to induce reluctant witnesses to testify while denying any such persuasive techniques to the defense.

\section{CONCLUSION}

When Singleton I was announced in July of 1998, the opinion reintroduced the legislative, judicial, and executive branches to a short statute that had been little-noticed in the thirty-five years since its enactment. Although Singleton I was quickly vacated, the reaction to the case has been significant. Unfortunately, the discussion of subsection 201(c)(2) invoked by the Singleton I decision has focused exclusively on the propriety of allowing prosecutors to exchange leniency for criminal witness testimony, without addressing the underlying

138. Freeing defense counsel to attempt to induce testimony from a witness raises two practical problems which are beyond the scope of this Note. First, if both the prosecution and defense can offer compensation (including money) for a witness's testimony, that raises the specter of an unseemly bidding war for helpful testimony. It seems likely that the jury would view this as a bribe, or at least not credible testimony, if the price was driven up too much. Second, the ability to offer financial compensation or inducement may well be of only theoretical comfort for most defendants. Most criminal defendants will lack the resources to offer much to induce a witness to testify, and that amount will likely be less valuable to the witness than the plea agreement offered by the government. All the same, the defendant at least has an opportunity equal to that of the government in securing helpful testimony. 
question of whether a criminal defendant can receive a fair trial if the prosecution can induce witnesses to testify while defendants cannot.

Federal prosecutors' plea bargaining with criminals in exchange for testimony, although longstanding practice, seems to violate subsection 201(c)(2) and that statute's concern for maintaining the integrity of witnesses' testimony. Simply creating a government exception is not an adequate solution because "if the judicial process is tainted by the admission of unreliable testimony induced by a defendant's promises, it is no less tainted by the identical actions of the prosecutor." ${ }^{139}$ As Johnston has argued, "compensating a witness for testifying involves an identical threat to the integrity of the judicial system whether the witness testifies for the prosecution or the defense. There is no apparent reason why the rules should be different for the two sides in a criminal case ...." ${ }^{140}$ If the initial impetus for enacting subsection 201(c)(2) over thirty-five years ago was to protect the witness stand from taints of false testimony, then that should be a factor in deciding the best course of action now.

Courts have routinely found that the jury is capable of assessing the credibility of testimony offered by a witness induced to testify by a plea bargain, provided the terms of the plea agreement are disclosed by the prosecution. The same reasoning should apply to agreements exchanging consideration for testimony between defense attorneys and defense witnesses. As long as there is no intent to corrupt the testimony, which would constitute an illegal bribe, then there is no reason that the same rules should not apply to both parties. By repealing the gratuity statute and creating the same disclosure requirements for both prosecutors and defense attorneys, the credibility of witnesses will remain a question for the jury, but both parties will be playing by the same rules.

139. United States v. Lowery, 15 F. Supp. 2d 1348, 1353 (S.D. Fla. 1998).

140. Johnston, supra note 124, at 24. 